Frrat Üniversitesi Sosyal Bilimler Dergisi

The Journal of International Social Sciences

Cilt: 26, Sayı: 2, Sayfa: 131-139, ELAZIĞ-2016

\title{
THE QUEST FOR TANGIBLE POWER IN THE INTANGIBLE WORLD OF ABSURD IN HAROLD PINTER'S “OLD TIMES"
}

\author{
Harold Pinter'in “Eski Zamanlar” Oyununda Uyumsuz Soyut Dünyada Somut Güç Arayışı \\ Volha KORBUT SALMAN* \\ ABSTRACT
}

Harold Pinter sets his plays in contemporary society, embellishes them with realistic settings and natural dialogue. The realism of the presentation serves as a deception, masking the absurdity underlying modern existence. Consequently, his characters use various strategies to cover up the loss of identity in the absurd world, the most prominent of which is the assertion of power that allows the temporary sense of meaning. "Old Times" (1970) is no exception from the pattern. The whole motion of the play depends upon the vigor of the power contest among its characters - Kate, Deeley and Anna, as well as Kate's final triumph over the two. As a result, the paper argues that "Old Times" serves as a model of power structure, in which characters attempt to dominate each other in order to counter the uncertainty, insecurity and loneliness arising from the absurdity of human condition.

Keywords: "Old Times", Pinter, absurdity, ambiguity, power

\section{ÖZET}

Harold Pinter oyunlarını modern toplum içinde kurgular, ve oyunlarına gerçekçi ortam ve doğal diyalog ile renk katar. Sunuşun gerçekçiliği bir yanılsama doğurarak, modern varoluşun temelindeki absürtlüğü gölgeler. Sonuçta, karakterleri absürt bir dünyada kimliklerin yok oluşunu gizlemek için çeşitli yollar kullanır; bunların en önemlisi anlamın geçiciliğine imkan tanıyan güç iddiasıdır. "Eski Zamanlar" (1970) da bu eğilimin dışında değildir. Oyunun devinimi karakterler - Kate, Deeley, Anna - arasındaki güç yarışının şiddetine, ve Kate'in diğer ikisi üzerindeki zaferine bağlıdır. Sonuç olarak, makale "Eski Zamanlar"'ın, insanın absürtlüğünden kaynaklanan belirsizlik, güvensizlik ve yalnızlık karşısında karakterlerin birbiri üzerinde hüküm kurmaya çabaladığı güç yapısı modeli olarak işlev gördüğünü söylemektedir.

Anahtar Kelimeler: "Eski Zamanlar", Pinter, absürtlük, belirsizlik, güç

\section{INTRODUCTION}

In the Nobel lecture, entitled "Art, Truth and Politics", Harold Pinter wrote that "there are no hard distinctions between what is real and what is not, nor between what is true or false. A thing is not necessarily either true or false; it can be both true and false" (2006: 1). The stance forms the foundation for the majority of his plays, in which characters create the past according to the emotional or tactical needs of the moment, in order to battle the meaninglessness and ambiguity of the present.

Pinter sets his plays in contemporary society, embellishes them with realistic settings and natural dialogue. What is more, "the wonderful thing about Pinter is that he really writes about people. And the extraordinary way in which ordinary people's minds work. Ordinary people don't behave like people in a well-made play, where you follow one line of direction" (Rogers, 1973: 8). Nevertheless, the realism of the presentation serves as a deception, masking the meaninglessness underlying modern existence. Therefore, the playwright's characters lack the 'curriculum vitae', typical of the twentieth century realist dramatists, and are presented as simply representatives of the middle-class, devoid of biographical data, social status and factual relations. Indeed, "characters don't wish to be 'known', and rarely offer a convincing explanation of themselves" (Naismith, 2000: 8). Hence, the only true entity in Pinter's works is the place where the plays are set, be it, typically, an enclosure, a room, a shelter, or a prison, providing characters with a sense of momentary certainty. It is 'the room' that "literally defines the living perimeters of the inhabitants,

\footnotetext{
* Instructor Dr., Y1ldırım Beyazıt University, School of Foreign Languages, ANKARA Mail: olgakorbut@gmail.com
} 
and the action of the play, in part, focuses on who is in control of the room. The stage becomes the space in which characters try to dominate and take, or keep, possession" (Naismith, 2000: 4). All the rest of the concepts, be it memory, time, emotions, future aspirations, lose their meaning and serve as a camouflage, disguising the inner guilt, secrets, anxiety, uneasiness and restlessness of the main characters, adding to the sense of insecurity, utter vulnerability, loneliness and loss of identity. Consequently, the characters use various strategies to cover up these feelings, the most prominent of which is the struggle for the assertion of power that allows the temporary sense of meaningful existence. All the above mentioned characteristics associate Pinter's plays with the world of the absurd, in general, and the Theatre of the Absurd, in particular, which aims to shock its audience out of complacency, to bring it face to face with the harsh facts of the human situation [...] to accept the human condition as it is, in all its mystery and absurdity, and to bear it with dignity, nobly, responsibly; precisely because there are no easy solutions to the mysteries of existence, because ultimately man is alone in a meaningless world. The shedding of easy solutions, of comforting illusions, may be painful, but it leaves behind it a sense of freedom and relief (Esslin, 1980: 15).

"Old Times", written in 1970, is no exception from the pattern underlying the majority of Pinter's works. The whole motion of the play depends upon the vigor of the power contest among its characters - Kate, Deeley (Kate's husband) and Anna (Kate's friend), as well as Kate's final triumph over the two. Thus, on the outer level Deeley and Anna are clearly engaged in a verbal, physical and even artistic battle over Kate, who, nevertheless, emerges victorious via her disturbing remoteness. Thus, "individual freedom from arbitrary power becomes one of the principal themes of [Pinter's] politics" (Grimes, 2005: 15). On the inner level, the play presents a continuous reflection on the notions of time and memory to provide the characters with necessary ammunition for their power struggle. In this connection, the extensive treatment of the time concept serves as a direct reference to Pinter's general standpoint observed in most of his plays that the past is no more fixed or certain than the present or the future, and can be both easily constructed and no less easily destroyed. The playwright often castigated himself for his initial ignoring of the role of time in the conflict of opposite sides: "I in common with a great body of people have been sleepwalking for many years, really, and I remember years ago I regarded myself as an artist in an ivory tower" (Knowles, 1989: 25). Yet, as "Old Times" clearly shows, his stance has radically changed ever since.

The paper argues that Pinter's "Old Times" is a model of power structure, in which characters attempt to dominate each other in order to counter the uncertainty tormenting their inner selves and their relationships with others, as well as the fear of insecurity and loneliness arising from the ambiguity of the concept of time and the overall absurdity of human condition. In this respect, Deeley employs the illusory certainty of the present, constructed memories of the past, the impact of art, masculinity, physicality and boasting, as well as verbal assaults to overpower Anna in their ongoing fight for Kate. Anna, in her turn, attempts to battle the fear of losing her old friend by means of numerous references to mutually experienced situations, frequent recourse to the power of art, significant knowledge of Kate's bodily habits and the power of female intimacy. Hence, Kate is forced to assert her identity so as to avoid the danger of being appropriated by the two. She triumphs in this undertaking by resorting to silences, withdrawals and pauses, as well as employing the power of deception to play the victim role. As a whole, the play attempts to convert individual minds to a more accurate, open-minded, progressive awareness of power games which they come across every single day of their lives and to make them become "not just flattered spectators killing an hour an idle hour with an ingenious and amusing entertainment; [but] guilty creatures sitting at a play; and the technique of pastime is no more applicable than at a murder trial" (Shaw, 2010: 157). 


\title{
Characters as Symbols of Power Struggle in Harold Pinter's "Old Times" Deeley's Frustrated Masculinity
}

The sense of uncertainty tormenting Deeley's personality is introduced at the very beginning of the play, when Kate, through the ambiguous answers regarding Ann's personality, shatters her husband's illusionary belief in the 'full ownership' of his wife:

\author{
Kate: Dark. \\ Deeley: Fat or thin? \\ Kate: Fuller than me. I think. \\ Deeley: She was then? \\ Kate: I think so (Pinter, 1988: 4).
}

The situation becomes more complicated by Deeley's shocking discovery that Kate and Anna once lived together:

Deeley: I knew you had shared with someone at one time...

Pause

But I didn't know it was her.

Kate: Of course it was (Pinter, 1988: 13).

Deeley's role of a husband, sole mate and provider of Kate's happiness gets assaulted by the "undisclosed lies [...] and faded lives in the false fronts of existence, [and he falls] prey to that state where in the mind that which belongs to us of life present and past becomes a shadow" (Ando, 2009: 213). This fact instigates the former to resort to every single possible means to reinstitute his power over Kate so as not to lose her to Anna. Hence, Deeley takes advantage of his extensive knowledge of his wife's present, which is seemingly concrete and tangible, in order to contest Anna in her argumentation of being the sole master of Kate's past: "She likes taking long walks. All that. You know. Raincoat on. Off down the lane, hands deep in pockets. All that kind of thing" (Pinter, 1988: 17). The similar line of reasoning may be applied to the following information provided by Deeley: "She hasn't many friends, although there's been every opportunity for her to do so" (Pinter, 1988: 19). As a result, the former attempts to portray himself as a considerate husband, able to provide a good social circle for his spouse, questions Anna's ability to endow Kate with similar care and attention in the past.

Deeley does not miss a chance to display his masculinity as an archetypal antagonism to the power of female bonding: "Well, any time your husband finds himself in this direction my little wife will be only glad to put the old pot on the old gas stove to dish him up something luscious of not voluptuous. No trouble" (Pinter, 1988: 37). The similar approach can be observed in Deeley's description of Kate's disorderly nature, in which he blames his wife for lacking "any sense of fixedness, any sense of decisiveness, but compliant only to the shafting winds" (Pinter, 1988: 31). Furthermore, Deeley is always eager to demonstrate his virility and sense of ownership, declaring that "After all, I am her husband" (Pinter, 1988: 52). The episode of glancing up Anna's skirt in the Wayfarer pub once again underlines his need to demonstrate his masculinity: "You sat on a very low sofa, I sat opposite and looked up your skirt. Your black stockings were very black because your thighs were so white. That's something that's all over now, of course, isn't it, nothing like the same palpable profit in it now, it's all over" (Pinter, 1988: 47). As a consequence, Kate's husband deflates his counterpart's ongoing pretension at "palpabil[ity]" (Pinter, 1988:47), due to the possible 'tangible' presence of the first signs of aging. In this way Deeley reduces Anna to the level of a "darling of a saloon bar" (Pinter, 1988: 45) so as to counter her claim of being a bohemian high-flier.

Deeley is "comically obsessed with the creative and destructive possibilities of verbal play" (Diamond, 1985: 159). Therefore, he launches a full-blown attack on Anna's a bit archaic choice of words, which endows the former with an additional opportunity to take control on the stage: "The word lest. Haven't heard it for a long time" (Pinter, 1988: 15). The same line of reasoning may be observed further on through the play: “The word gaze. Don't hear it very often” (Pinter, 1988: 22). 
Hence, the hint at the outdated nature of Anna's lexicon serves as an allusion to the antiquated essence of her friendship to Kate.

Deeley, as well as other characters in "Old Times", have a profound recourse to memory as an indispensible element in any power game and a corner-stone in the assertion of one's identity and construction of the past according to the special needs of a moment. They are incessantly "trying to pin down reality, trying to pin down the truth" (Batty, 2005: 165), which seem to be unattainable in the absurdity of the modern world. In fact, memory, as the play shows, can operate on a variety of levels. First, it can offer a fiction that takes on the reality of a fact. Thus, Deeley describes the improbable encounter "somewhere in the Westbourne Grove" (Pinter, 1988: 47) with two girls, seated together, and him "gaz[ing] at [them] both, at both of [their] thighs" (Pinter, 1980:47). Hence, memory is presented as a possible construct of imagination brought into being due to the tension of Deeley's current situation - being dangerously trapped between two women attempting to deconstruct his beliefs. In the process of recollecting the past one can also create the future. Thus, Deeley remembers Kate and Anna's sudden disappearance from the party, as if to foreshadow a complete break up of relationship with the two at the end of the play: "I wondered over to the sofa. There was no one in it" (Pinter, 1988: 48). In a world where nothing is verifiable, memory can also be a weapon of psychological domination. Thus, Deeley describes his first meeting with Kate in a language indicative of crude sexual exploitation: "I thought, Jesus this is it, I've made a catch, this is a true-blue pickup" (Pinter, 1988: 26). These words serve as an antipode to Anna's refined description of intimacy.

The threat to destroy Deeley's formal ownership of Kate makes the character struggle to reestablish his authority. He does so by means of boasting about his deep involvement in art and movie-making, about his profound knowledge of Anna's home town in Sicily, and about his status of a genuine artist in a world of commercial prostitutes. Thus, Deeley brags: "I had a great crew in Sicily. A marvelous cameraman. Irving Shultz. Best in business. We took pretty austere look at the women in black. The little old women in black. I wrote the film and directed it. My name is Orson Welles" (Pinter, 1988: 38). Despite the monumentality of the statement, the 'tangible untruth' of the assertion casts a shade of suspicion on every other account of the past.

Deeley makes an effort to defeat Anna by displaying a profound knowledge of his wife's bodily habits. Thus, he makes a show by narrating Kate's shower habits: "She's both thorough and, I must say it, sensuous. Gives herself a comprehensive going over, and apart from everything else she does emerge as clean as a new pin" (Pinter, 1988: 49). As a result, by the middle of Act II, Deeley emerges as a specialist in both, Kate's psychology and physiology. Yet, by "continually raising the stakes on intimacy [and] eroticizing his wife [Deeley simply] exposes his own frustrated desire" (Diamond, 1985: 162) rather than genuine intimate relationship with his wife.

It is again Deeley who initiates a song contest and, as a result, caps all Anna's quotations. In fact, the songs presented in the work reinforce the play's basic theme of remembrance - "The memory of all that...No, no, they can't take that away from me..." (Pinter, 1988: 54) - endowing the past with imaginative truth, so as to assert one's personality and to 'create' the past according to one's arising needs. Yet, most of Deeley's attempts to take control over the situation and over Kate are craftily tackled by Anna - an experienced and skilful player in the game of supremacy. As a consequence, Deeley's constant need to prove his authority in the family undermines his dominance and makes us "see the question of who will occupy the dominant position within the marriage as inseparable from the larger question of whether the family will serve as a stable site for the articulation of patriarchal power or as the vanishing point that works to undermine that power and the cultural order it supports" (Silverstein, 1993: 24).

\section{Anna's Dialectic of Seductive Domination}

From the very beginning of the play Anna penetrates into Kate's and Deeley's commonly inhabited space and reverberates T.S. Eliot's question: "Who is the third who walks always beside 
you?" (Eliot and Rainey, 2006: 68). The heroine attempts to appropriate the past and to lay claim to a prior intimate knowledge of Kate despite Deeley's official rights to his wife. In doing so, Deeley's opponent opts for memories, no matter factual or not. The recreation of fictive past, which only seems to have taken place, suits Anna perfectly. She states that "there are things I remember which may never have happened but as I recall them they take place" (Pinter, 1988: 28). This phrase emphasizes the overall absurdity of the situation taking place between the three characters, as well as her fear of losing Kate, and reveals her personal vulnerability.

It is in the past that Ann finds her identity, while at present it is tormented by the lack of meaning. Thus, Anna describes her artful London life she led with Kate, endowing the apparent fiction of the situation with the veracity of truth: "riding on top of the bus down Kensington High Street, and the bus conductors, and then dashing for the matches for the gas fire and then I suppose scrambled eggs, or did we? Who cooked? Both giggling and chattering, both huddling to the heat, the bed and sleeping" (Pinter, 1988: 13). The very presence of the rhetorical questions "or did we?" (Pinter, 1988: 13) and "who cooked?" (Pinter, 1988: 13) emphasizes the fact of Anna's probable 'creation' of the situation for the purpose of defeating Deeley. This fact justifies the common claim that "on Pinter's territory every question is an attempt to control and every answer is a swift evasion" (Bryden, 1971: 27). In addition, to validate her stance Anna makes frequent references to 'real' place names, as opposed to the 'unreal' nature of her present situation, such as "the Albert Hall, Covent Garden[,] Kensington High Street" (Pinter, 1988: 13) and "Green Park" (Pinter, 1988: 14), as a sort of supporting evidence. Besides, in the process of remembering the past, Kate's friend foreshadows the future: "This man crying in our room...There was nothing I could do. I undressed and switched out the light and got into my bed...the man came over to me, quickly, looked down at me, but I would have absolutely nothing to do with him, nothing" (Pinter, 1988: 28). Thus, through the description of a stranger in the room she once shared with Kate, Anna emphasizes the fact that "their relationship [with Kate] was severed by the intrusion of Deeley" (Baker, 2008: 79), and hints at the possibility of Deeley being 'that' man, as well as foresees the calamity of the final moment of the play.

The heroine is using memories as a weapon of emotional control:

I remember on Sunday she said to me, looking up from the paper, come quick, quick, come with me quickly, and we seized our handbags and went, on a bus, to some totally obscure, some totally unfamiliar district and, almost alone, saw a wonderful film called Odd Man Out (Pinter, 1988: 34).

Hence, Anna reinvents the past to suit her own purposes, by claiming that she was the first to watch the film with Kate, and reinforces the strength of the conspiratorial female intimacy.

Anna combats Deeley's crude virility and denies the dogmatic vision of a woman as a housekeeper with an air of artistic refinement and sophistication: "the cafes we found...where artists and writers and sometime actors collected, and others with dancers, we sat hardly breathing with our coffee, heads bent, so as not to be seen, so as not to disturb, so as not to distract, and listened to all those words" (Pinter, 1988: 14). Thus, she raises her relationship with Kate one step above the trivial and house-bound one she experiences with Deeley.

Kate's friend capitalizes on every chance to underline the mediocrity and absurdity of the present, as compared to the romantic meaningfulness of the past: "How wise you were to choose this part of the world, and how sensible and courageous of you both to stay permanently in such a silence" (Pinter, 1988: 15). The contrast between two different lives is accentuated with a newer force, making irrelevant all the previous hints at the subjective nature of one's memories. Moreover, Anna strives to destroy the seemingly secure atmosphere of the couple's married life in her drive to win the game of power. The former's allusion to Kate's possible adulteries in Deeley's frequent absences becomes rational: "You live your wife for such long periods? How can you?" (Pinter, 1988: 35). Hence, Anna succeeds in undermining Deeley's sense of security and increases his vulnerability. 
Anna manages to create a feeling of homely comfort, which might be possibly absent from Kate's everyday existence: “Don't let's go out tonight, don't let's go anywhere t night, let's stay in. I'll cook something, you can wash your hair, you can relax, we'll put some records" (Pinter, 1988: 39). As a result, Kate's friend questions Deeley's ability to create a real and tangible atmosphere of repose and consolation for his wife, as opposed to the indistinct world that he immersed her into.

Contrary to Deeley's beliefs, Anna is far from being ignorant of Kate's bodily needs: "She floats in the bath. Like a dream. Unaware of anyone standing, with her towel, waiting for her, waiting to wrap it round her. Quite absorbed. Until the towel is placed on her shoulders" (Pinter, 1988: 50). Thus, Deeley's female adversary shows more than just ordinary acquaintance with Kate's habits. It is more like deep knowledge embellished with utter fascination. What is more, the account "lays bare the power hierarchy among three characters: Anna supervises the bath, while Deeley merely assists" (Diamond, 1985: 174), which registers Deeley's ultimate defeat.

Both Deeley and Anna are engaged in the battle of memory and intellect over Kate, and are driven by the ultimate fear of losing both, the latter and their common past - the only abode of their meaningful existence in the world of absurd. "For much of the play they have sought to impose contesting interpretations on Kate's identity and the past; their increasing urgency in doing this implies a desperate need to shape a role for Kate, which will somehow confirm their own troubling existences" (Cave, 2001: 122). Kate, in turn, commoditized and victimized in the course of the play, succeeds to emerge victorious at the end of the work by dominating both, her husband and her female friend.

\section{Kate's Pallid Mystery}

As the play opens, Kate resorts to the use of pauses to create the sense of ambiguity surrounding her identity, making Deeley impotent to assert his authority:

Deeley: Your best and only.

Kate: My one and only.

Pause

If you have only one of something you can't say it's the best of anything.

Deeley: Because you have nothing to compare it with?

Kate: Mmnn

Pause (Pinter, 1988: 5)

As the play progresses Kate chooses to remain silent, only making occasional remarks of minimal significance. In fact, Kate is simply not willing to communicate, rather than not being able to. The heroine is guided by her desire to conceal her genuine intentions from the rest of the characters and to retain her invulnerability. In fact, "one way of looking at speech is to say that it is a constant stratagem to cover nakedness, and we communicate only too well in our silence, in what is unsaid, and what takes place is a continual evasion, desperate rearguard attempts to keep ourselves to ourselves" (Pinter, 1998: 20). Anna and Deeley are forced to figure out what is not being said by Kate, emphasizing the fact that silence speaks more than words. What is more, Kate seems to enjoy the role of the victim, being seemingly commoditized by the other two characters. Some critics compare Kate to "'the other' in Roland Barthes' A Lover's Discourse, 'a mere object, like a stuffed doll,' whose wordly voice Anna and Deeley silence because it opposes the body they once tried to possess" (Diamond, 1985: 171). Yet, Kate capitalizes on the opportunity, which endows her with an invaluable chance to listen, to concentrate and to gather forces before striking the final blow at the end of the play. In fact, Kate makes a hint of her ultimate intentions in the middle of Act I, by expressing her absolute boredom with Deeley's constant domestication. Hence, she articulates her sheer interest in the interior of Anna's house:

Deeley: I suppose his business interests kept him from making the trip. What's his name? Gian

Carlo or Per Paolo? 
Kate (To Anna): Do you have marble floors?

Anna: Yes.

Kate: Do you walk in bare feet on them? (Pinter, 1988: 38)

The audience catches a glimpse of the latent form of Kate's inner rebelliousness, which is driven by her ultimate desire to battle ambiguity and lack of meaning permeating her life with Deeley, and to assert dominance both, over her own self and the other two counterparts.

The first manifestation of Kate's real intentions appears towards the middle of Act II. Anna and Deeley discuss the heroine's overall helplessness in life, which, as an example, is manifested in Kate's alleged inability to dry herself up after a bath and "to detect the place of the highest density of moisture on [her] body" (Pinter, 1988: 52). To contradict the two, Kate "comes into the bedroom...wear[ing] a bathrobe" (Pinter, 1988: 53), not only dried and dressed, but also implying that she does not actually need any one of them. Hence, the heroine receives one more point in the power game with Anna and Deeley.

What is more, Kate undermines Deeley's superior claim of possession by originating the talk about all the male friends she used to have, contrary to her initial claim of having no one but Anna as the best and the only mate:

Kate: Is Charley coming?

Anna: I can ring him if you like.

Kate: What about McCabe? (Pinter, 1988: 58)

Kate puts a special emphasis on the downright unreliability and absurdity of words and memory, which are mainly employed to fit one's special purposes and instantaneous emotional conditions.

Kate dismantles Deeley's image as paragon of virility by describing the latter as "sensitive [and] vulnerable" (Pinter, 1988: 66), so "unlike the others...brutish and crass" (Pinter, 1988: 67). As a result, she tears down all the previous allegations of her shyness, "folding herself from [men]" (Pinter, 1988: 60) and inability to face and judge the opposite sex. Once Deeley is 'floored', the play moves into its last phase, featuring the final combat between women only.

In this connection, in the first lengthy speech Kate advocates her preference of the country life over that of London: "I always find the water very hard in London. That's one reason I like living in the country. Everything is softer. The water, the light, the shapes, the sounds. There aren't such edges here" (Pinter, 1988: 55). As a result, she totally discredits the validity of Anna's memories of their shared city life, and it is Kate now, who initiates the return into the past, which the other two characters have to follow silently. In fact, Kate's final speech presents a ruthless demolition of Anna, her supposedly truthful memories, her sexual sophistication and her possessive claim to the heroine's life, by making a direct reference to the standpoint elaborated by Anna at the very beginning of the play: "there are things I remember which may never have happened but as I recall them so they take place" (Pinter, 1988: 28). By doing so, Kate underlines the utter fallibility of memory, which is greatly influenced by the schemes of the individuals employing it for their own private purposes.

Yet, Kate saves the final blow to her opponents' pretensions for the very end of the play when she narrates an imaginative story of Anna's death, portraying her corpse defiled with dirt and disfigurement: "You lay dead, your face scrawled with dirt, all kinds of earnest inscriptions, but unblotted, so that they had run, all over your face, down to your throat...Your pupils weren't in your eyes. Your bones were breaking through your face" (Pinter, 1988: 68). In fact, Kate does not stop here and describes the instance of violating Anna's bed after the removal of her cadaver, and plastering Deeley's face with dirt from the window box:

When I brought him into the room your body of course was gone... We had a choice of two beds. Your bed or my bed. To lie in, or on. To grind noses together, in or on. He liked you bed, and though he was different in it because he was a man. But one night I said let me 
do something, a little thing, a little trick...I dug about the window box, where you planted out pretty pansies, scooped, filled the bowl, and plastered his face with dirt. He was bemused, aghast, resisted, resisted with force (Pinter, 1988: 69).

Kate deconstructs the intangible notion of truth, by blending the past, present and future in an absurd, but, nevertheless, tangible story, which assembles its own truth according to the power needs of an individual. "She buries [Anna and Deeley] with her own talk of the past and invades their fictions in present time" (Diamond, 1985: 177). As a result, all the previous accounts of Kate's life rendered by Deeley and Anna become not only unreliable, but also completely absurd. "Kate shows them that their identities are compounded of nothing beyond a will to gain power over her; they have no inner resources whatever, no depth. In that ending she looks out confidently into the future; but they are locked in the past" (Cave, 2001: 122). Kate's story questions the overall validity of Anna's friendship and the whole record of her marriage to Deeley.

The play closes with a graphic image containing a 'replay' of the bedroom scene described in Act I, in which Deeley "starts to sob, very quietly...goes to Anna's divan [and] looks down at her... moves to the door...turns, goes towards Kate's divan ...lies across her lap" (Pinter, 1988:70) and, finally, falls into the armchair where "he sits slumped" (Pinter, 1988: 70). At the very end of the performance, the lights come up very brightly, as opposed to the overall grimness of the play, signifying not only Kate's ultimate triumph in the power game with Deeley and Anna, but also the fact that the struggle for power becomes the only means of constructing tangible reality in the world tormented by absurdity, intangibility, solitude, and unreliability of memories and identities.

\section{CONCLUSION}

To conclude, Harold Pinter's play "Old Times" exhibits a model of power structure, in which each character strives for domination, so as to fight the insecurity torturing their inner selves and their relationships with others, as well as the overall absurdity and loneliness overwhelming their lives. In the course of the play the power struggle runs in the following directions: Anna versus Deeley and vice versa, in which the characters are guided by the desire to gain control over Kate; and Kate versus Deeley and Anna, in which the heroine attempts to deconstruct her role of a victim and a commodity, and to assert her own identity. The trio uses various techniques in their quest for power, including frequent references to the unreliability of time, in general, and memories, in particular, which serve as a deadly weapon in the combat for authority, assembling the past according to the strategic requirements of the moment, foreshadowing the future, and getting the most out of the present. The characters make an extensive use of details, verbal assaults, and hints at physical intimidation, silences and pauses, victimization, commodification, profound knowledge of personal habits, contrast between artistic sophistication and crude physical force, as well as the strength of female bonding in order to attain control over the opponents. Kate emerges as a winner in the power game; yet, the final frozen state of the three characters, enclosed in a temporary sanctuary of a room in a country house, is indicative of their common anxiety about the overall absurdity, memory-wise ambiguity, increased loneliness, vulnerability and identity crisis typical of contemporary existence. Hence, the quest for power becomes the only tangible survival tactic in the overall intangible pandemonium of modernity.

\section{REFERENCES}

Ando, Roberto (2009). "Ritratto di Harold Pinter", Viva Pinter. Harold Pinter's Spirit of Resistance, (Editor) Brigitte Gauthier, Peter Lang, Oxford.

Baker, William (2008). Harold Pinter, Continium, London.

Batty, Mark (2005). About Pinter: the Playwright and the Work, Faber and Faber, London.

Bryden, Ronald (1971). "Pinter's New Pacemaker", The Observer, 6 June.

Cave, Richard Allen (2001). "Body Language in Pinter's Plays", Harold Pinter, (Editor) Peter Raby, Cambridge University Press, Cambridge. 
Diamond, Elin (1985). Pinter's Comic Play. Lewisburg Bucknell University Press, London and Toronto.

Eliot, Thomas Stearns and Rainey, Lawrence (2006). The Annotated Waste Land with Eliot's Contemporary Prose, Yale University Press, New Haven.

Esslin, Martin (1980). The Theatre of the Absurd. Introduction, Penguin, Middle Sex.

Grimes, Charles (2005). Harold Pinter's Politics. A Silence Beyond Echo, Fairleigh University Press, Madison and Teaneck.

Knowles, Ronald (1989). "Harold Pinter, Citizen”, Pinter Review, Vol. 1.

Naismith, Bill (2000). A Faber Critical Guide to Harold Pinter, Faber and Faber, London.

Pinter, Harold (1988). Old Times, Methuen Drama, London

Pinter, Harold (1998). Various Voices: Prose, Poetry, Politics, 1948-1998, Faber and Faber, London

Pinter, Harold (2006). Art, Truth and Politics. A Nobel Lecture, Faber and Faber, London.

Rogers, Paul (1973). “An Actor's Approach: Interview with Paul Rogers”, A Casebook on Harold Pinter's The Homecoming, (Editors) John Lahr and Anthea Lahr, Davis-Poynter, London.

Shaw, George Bernard (2010). The Quintessence of Ibsenism, Now Completed to the Death of Ibsen, Constable \& Co., Michigan.

Silverstein, Marc (1993). Harold Pinter and the Language of Cultural Power, Associated University Presses, London and Toronto. 